Journal of Economics and Behavioral Studies

Vol. 7, No. 3, pp. 63-75, June 2015 (ISSN: 2220-6140)

\title{
The Influence of Supplier Involvement on Communication, Relationship Longevity and Business Performance in Small, Medium and Micro Enterprises in South Africa
}

\author{
Richard Chinomona, Progress Hove \\ University of the Witwatersrand, South Africa \\ Vaal University of Technology, South Africa \\ Richard.Chinomona@wits.ac.za
}

\begin{abstract}
Most firms are increasingly realizing the benefits of involving the outside suppliers by considering their manufacturing processes and technological capabilities, especially regarding quality, time to market, configuration, control and cost. Nevertheless, in the context of small to medium enterprises (SMEs), scant attention has been given to the empirical investigation into the influence of supplier involvement on business performance. The purpose of this study was to examine the influence of supplier involvement on business performance and the mediating role of communication and relationship longevity among SMEs in South Africa. Five hypotheses were posited and sample data of 302 were collected from Gauteng Province of South Africa, to empirically test these hypotheses. The results of this study showed that, supplier involvement has influence on communication, relationship longevity and business performance in SMEs context in South Africa. The managerial implications of the findings are discussed and limitations and future research directions are indicated.
\end{abstract}

Keywords: Supplier involvement, Communication, Relationship longevity, Business performance, Small, Medium and Micro Enterprises

\section{Introduction}

The current received wisdom is that supply chain management has become an important determinant of sustainable competitive advantage for firms worldwide. The contemporary supply chain management accentuates on how to maximize the overall value of the firm and enhance performance through effective communication of information and the long term relationships that result from integration of supply chain partners. It is argued that supplier involvement in new product development is augmenting in importance recently (Wisner, 2003). Thus, supplier involvement is advocated to provide vast opportunities for firms to improve their project electiveness in terms of low product costs and high quality as well as project science on the aspect of development costs and time (Ulaga \& Eggert, 2006). Increasingly, manufacturing firms today are involving suppliers in the development of their new products in order to cope with the ongoing challenge of increased global competition and maximizing customers' satisfaction in high innovation, quality and low cost demanding market conditions (Wisner, 2003). Supporting this observation is a growing body of recent empirical business to business (B2B) marketing literature devoted to explore the supplier relationship management issues, such as supply base consolidation (Eggert \& Ulaga, 2010), supplier portfolio management (Wagner \& Johnson, 2004), value creation through key relationship status (Ulaga \& Eggert, 2006), and the supplier relationship management framework (Moeller, Fassnacht \& Klose, 2006).

Supply chain success depends on the ability of the supply chain partners' management to assimilate the various goals and strategies of diverse supply chain partners (Corsten \& Felde, 2005). In other words, these joint efforts are achievable by developing long term supplier-buyer relationships combined together by effective communication of essential information. Thus, the endorsement of both the supplier and customer's efforts in the value creation process is required, which suggests the need to further investigate the influence of supplier involvement on communication and key supplier long term relationship management as well as the ultimate effect on business performance. Key supplier-buyer long term relationship in this paper focuses on the management of strategic relationships that emanate from the buyer-seller exchanges. Previous literature suggests that key partner relationships must be considered as the main source of competitive 
advantage (Wisner, 2003) and a podium for value differentiation in supply chains that results in enhanced business performance(Ulaga \& Eggert, 2006). For instance, studies revealed that through profound dependence on their suppliers, the Japanese manufacturers brought new automobiles to market at a faster pace, through less effort (less development hours, and few engineers involved) and with more innovative features (Kamath \& Liker, 1994; Ragatz et al., 1997). More so, the extant literaturein this area reveals the importance of effective communication in building long term relationships with the key suppliers in buyerseller exchanges (Pressey, Winklhofer \& Tzokas, 2009).

However, the field suffers from serious gaps. Little attention has been paid to the effect of supplier involvement on communication of essential information between firms, longevity of the buyer-seller relationships between the firms, and ultimately the performance of the business of each firm. In fact, most studies on supplier involvement have investigated the antecedents to increased supplier involvements in radical innovations as well as new product performance outcomes of supplier involvement (Song \& Benedetto, 2008). These studies did not; however investigate the impact of supplier involvement on communication between the suppliers and their buyers. The previous studies did not consider the effect of supplier involvement on the longevity of the supplier-buyer relationships between firms. Moreover, the focus so far was on the new product performance outcome of supplier involvement, and less has been done to address the supplier involvement effect on business or firm performance. Thus, rarely can one find supplier involvement being studied as the predictor variable of business performance in supplier-buyer relationships of firms. In addition, little is known about communication and supplier-buyer relationship longevity as mediators for the relationship between supplier involvement and business performance. Moreover, the previous literature regarding the supplier involvement has concentrated mainly on larger firms, while little evidence is available for Small, Medium and Micro Enterprises (SMMEs). However, supplier involvement may be of greater importance even to those neglected SMMEs. A notable exception is the work of Song and Benedetto (2008) which investigated supplier involvement in new ventures. Hence, the main purpose of this study is to evince the impact of supplier involvement on communication of essential information, supplierbuyer relationship longevity and business performance, supply chain performance in SMMEs operating in South Africa.

SMME dependency on suppliers for potential investment, providing investment funds in return for a share of the SMME business or generated profits is augmenting recently (Song and Benedetto, 2008). According to Song and Benedetto (2008), when selecting from among potential suppliers, SMMEs qualify them on the basis of their skills and abilities, select the best suppliers as potential partners, conduct entrepreneurial marketing as appropriate to get them interested and involve them in the innovation, and encourage them to commit financial resources. Indeed, SMMEs may be critically dependent on their suppliers for the required and critical capabilities, and even for their improved performance in the marketplace. This paper therefore, seeks to examine the influence of supplier involvement in product development on communication of essential information, buyer-seller long term relationships and business performance of SMMEs. It seeks to determine the impact of supplier involvement on communication of essential information in SMME's buyer-seller relationships. In addition, this paper seeks to ascertain the influence of supplier involvement on SMME's buyer-seller long-term relationships. It also seeks to determine the influence of communication of essential information on SMME buyer-seller long-term relationships. Moreover, this paper seeks to ascertain the impact of communication of essential information on business performance of SMMEs. Lastly, this paper seeks to determine the impact of SMME buyer-seller long-term relationships on business performance. The remainder of the paper is structured as follows: literature review, which includes the theoretical, empirical review, conceptual model and hypotheses development. - Subsequent to this is the methodology section, then the findings as well as the conclusions and recommendations.

\section{Literature Review}

\section{Theoretical Background}

Relational View: The fundamental premise of the relational view theory is the resource-based view postulated by Penrose in 1959. This view extending from the resource based view, is formed on the basis that 
productivity gains in the value chain are possible, especially when the buyer-seller exchange partners are willing to make relation-specific investments and combine them in a unique way (Dyer \& Singh, 1998). The relational view advocates that successful business relational exchanges result from certain characteristics of the relationship, and these comprise communication, trust, commitment and cooperation (Mehta, Larsen, Rosenbloom \& Ganitsky, 2006; Wittmann, Hunt \& Annett, 2009; Muthusamy et al., 2007; Robson, Spyropoulou, \& Al-Khalifa, 2006). Supplier-buyer partnerships characterized by effective communication of essential information generate inter-firm trust, which promotes cooperation through supplier involvement in innovations and product developments (Sarkar et al., 2001). Effective cooperation, in turn, allows the partners to successfully combine their resources in ways that contribute to the development of competitive advantages and ultimately improve the business performance (Madhok \& Tallman, 1998). Thus, the relational view advocates that successful supplier-buyer exchange partnerships are characterized by trust, which results in relationship commitment and consequently free and effective communication of essential information, as well as effective cooperation among the partnering firms., (Wittmann et al., 2009). Thus, the notion that a firm's critical resources may span firm boundaries and may be embedded in inter-firm routines and processes (- (Robson et al., 2006), evinces the need for effective communication of essential information and commitment to strategic relationships in firm's supplier involvement practices, in order to enhance performance. Relating the relational view theory to the current study, this paper submits that an effort by SMME owners or managers to involve suppliers in their product development is likely to create a supportive inter-organizational environment to enhance effective communication of essential information. The other likelihood is that both firms may commit to long-term buyer-seller relationships. Furthermore, as a result of effective communication of essential information between the partners and in accordance to the relational view theory, partner's commitment to long-term buyer-seller relationships is likely to be raised and ultimately, SMME business performance -maybe enhanced. For this reason, supplier involvement in SMME product development will eventually lead to improved SMME business performance.

\section{Empirical Review}

Supplier Involvement: Supplier involvement as defined by Lau (2011) refers to the direct participation of the supplier during the product development processes. Most firms are increasingly realizing the benefits of involving the outside suppliers by considering their manufacturing processes and technological capabilities, especially regarding quality, time to market, configuration, control and cost (Burt, Petcavage \& Pinkerton, 2010). As such, more and more suppliers are becoming involved and active in their customers' development projects from the beginning, when they can have a major impact on performance, time, cost and quality (Burt et al., 2010). The involvement of suppliers in the customer-firm's project helps provide necessary information, as it includes expertise regarding new ideas and technology. This in turn helpsin identifying potential problems and enables the problems to be resolved timely. Partnerships with suppliers in product development require vast resources, comprising time, effort and money for the effective coordination and communication of essential information for both partnering firms. Supplier involvement is helpful in assuring that what is specified is also procurable and represents goods value (Leenders et al., 2002).

Communication: Effective communication refers to regular and genuine contacts between buying and selling firms, either personally or through technology enabled communication devices (Prahinski \& Benton, 2004). It can also be viewed as the hinge of the buyer-seller relationships between firms. Previous studies (Krause, 1999; Newman \& Rhee, 1990; Galt \& Dale, 1991) have revealed the essence of two-way and collaborative inter-organizational communication for successful buyer-supplier relationships. Thus, according to Carr and Pearson (1999), buyers and suppliers need to commit a greater amount of sensitive information and be willing to share sensitive design information so as to find joint solutions to material problems and design issues. Communication is essential to conduct dialogue, provide feedback and clarification in order to reduce ambiguity and uncertainty in any relationship (Prahinski \& Benton, 2004). Similarly, communication that is collaborative in nature is also important in building long-term buyer-supplier relationships, where the buyer firms involve their key suppliers in product development projects.

Long-term relationships: The longevity in the nature of supplier contracts is augmenting in importance recently. In such supplier contracts, more and more suppliers are expected to provide customers with 
information regarding their processes, quality performance, and even the cost structure (Chen \& Paulraj, 2004). The buyer-seller relating firms (through these close relationships) are more willing to share risks and incentives as well as sustaining their relationship over a longer period of time (Chen \& Paulraj, 2004). In addition, there are considerable changes in the contemporary nature of buyer-supplier relationships and these changes include three key aspects of supplier relationships which are: the current trend to build a longterm relationship with suppliers rather than short-term contracts (Ogden, 2006). Also, firms' current use of fewer suppliers over a longer period of time rather than keeping a large base of suppliers allows them to change suppliers for almost every contract. Lastly, the relationship with suppliers is currently being enhanced into the strategic level where suppliers are now considered as an integral part of the firm's operations (Kotabe, Martin and Domoto 2003; Chen \& Paulraj, 2004). These changes have resulted in several dimensions of collaboration, such as supplier involvement in product design and development, joint improvement program as well as profit and risk sharing (Chen \& Paulraj, 2004).

Business Performance: From a business perspective, understanding the antecedents of SMME performance has occupied an immense position in the extant business management literature. There seem to be a general recognition that supplier involvement enhances a firm's product performance and yet there is no general consensus on how to measure a firm's performance (Vorhies and Morgan, 2005). While some streams of product innovation research have tended to treat product performance as part of firm performance, this study seeks to measure profitability, sales growth, market share, as overall firm performance (Homburg and Pflesser, 2003; Hooley et al., 2005; Wong and Merrilees, 2007). Thus, business performance in this study is defined in terms of the SMME's profitability, sales volume, growth and market share.

Conceptual Model and Research Hypothesis: In order to empirically test the interrelationships between supplier involvement, communication, buyer-seller long term relationships (longevity) and business performance in SMMEs, a conceptual model is developed premised on the reviewed supply chain management literature. The conceptual model is grounded in the Relational View, which provides a solid foundation for the current study. In this conceptualized model supplier involvement is the predictor while communication and buyer-seller long term relationships are the mediators. Business performance of SMMEs is the single outcome variable. Figure 1 depicts this conceptualized research model. The hypothesized relationships between the research constructs will be discussed hereafter.

\section{Figure 1: Conceptual Model}

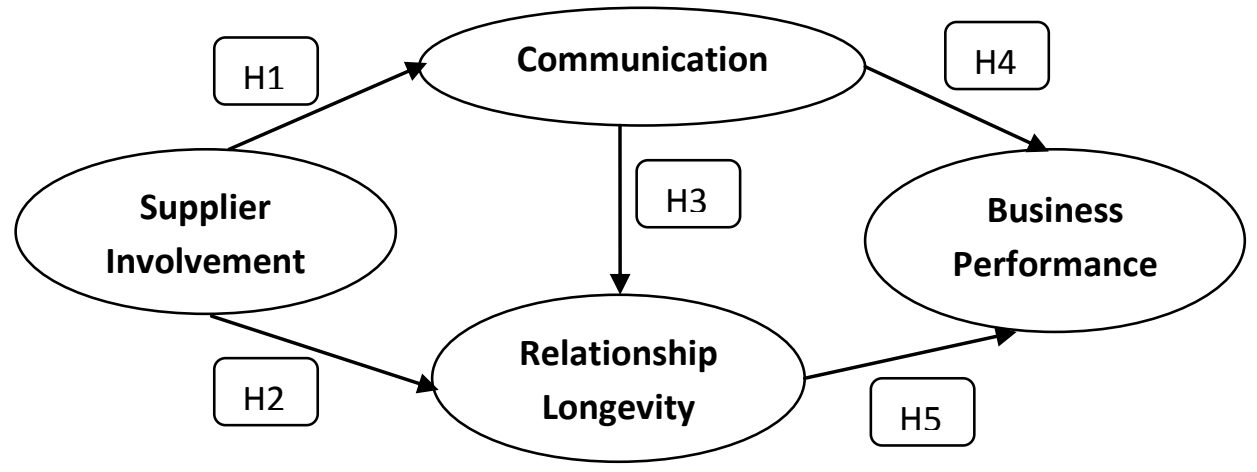

Supplier Involvement and Communication: Supplier involvement has gained considerable attention in supply chain management literature as a result of the value it creates to buying firms (Sahin \& Robinson, 2005). The supply chain literature reveals that properly timed supplier involvement in the buying firm's product development project is critical for facilitating the coordination and communication of essential information from the supplier to manufacturer and customer, as well as the backward flow from customer to manufacturer and supplier (Quesada, Rachamadungu, Gonzalez \& Martinez, 2008). There is a consensus in the literature that higher levels of supplier involvement in buying firms' product development projects lead to lower development costs, fewer engineering changes, higher quality with fewer defects, shorter time to market, highly standardized components, and detailed process data as well as efficient and effective 
communication of essential information between firms (Monczka et al., 2000; Igot 2007; Bonaccorsi \& Lipparini, 1994). Similarly, the current study submits that properly timed supplier involvement in the buying firm (SMMEs') product development influences the flow of essential, timely, accurate and quality information and eventually enhances communication between SMMEs and their suppliers. Previous studies have also found a positive relationship between supplier involvement through integrations and information sharing (communication of essential information) (Sahin\& Robinson, 2005) Hence, SMMEs' involvement of their suppliers in their product development project can be expected to increase the intensity and effectiveness of communication between buying firms and their suppliers in South Africa. Therefore, it can be hypothesized that:

H1: SMEs' supplier involvement in product development project positively influences their communication of essential information with suppliers.

Supplier Involvement and Relationship Longevity: Drawing from previous studies, supplier involvement in the buying firm's product development projects has a consequential significant impact on the establishment of long term buyer-supplier relationships (Madlberger, 2009). Supplier involvement has been previously linked to supplier dependence and commitment (Lau, 2011). The arguments raised are that involving suppliers in product developments of the buying firm helps to secure resources and capabilities needed for product innovation which the buying firm (SMME) does not have (Lau, 2011). On the other hand, supplier involvement helps the suppliers to learn about new technology by participating in the buying firm's new product development project (Athaide \& Klink, 2009). Thus, such dependence on each other for the mutual benefits will make the buying firm to relyon suppliers for itsnew product's success, while suppliers may depend on the buying firm for their own development. . This will in turn make both firms to commit themselves to the strategic buyer-supplier relationships, by investing in the relationships. Commitment has been defined by Lau (2011) as the degree to which the supplier feels obligated to continue business with the particular buying firm. As in Lau (2011), commitment in this study encompasses loyalty to and longevity of the buyer-supplier relationship. A study by Lau established a positive relationship between supplier dependence, supplier involvement and supplier commitment. This study similarly submits that supplier involvement has a positive influence on buyer-supplier relationship longevity. Therefore, it can be posited that:

H2: $\quad$ Supplier involvement in SMMEs' product development projects positively influences the buyer-supplier relationship longevity.

Communication and Relationship Longevity: The extant literature indicates that good and effective communication of essential information, participation and feedback facilitates the buyer-supplier relationship longevity (Prahinski \& Benton, 2004; Anderson, 1987). The arguments presented are that communication that is collaborative coupled with supplier development programs enhances the closeness and longevity of the buyer-supplier relationships (Prahinski \& Benton, 2004). Thus, for the buying firm, the primary objective of the supplier development program, through supplier involvement, is tomake use of few key suppliers to meet its current and future needs. Therefore, it is through the supplier development program communication efforts and effectiveness that the buyer-supplier relationship longevity is developed. Previous studies have linked collaborative communication to supplier commitment, coordination and satisfaction (Mohr, Fisher \& Nevin, 1996; Prahinski\& Benton, 2004). A study by Mohr et al. (1996) showed a significant relationship between collaborative communication, commitment, coordination and satisfaction. In support of this finding, Prahinski and Benton (2004) revealed that the use of collaborative communication has a positive influence on the supplier's perceptions of the buyer-supplier relationship. Similarly, this study, interprets the SMME's supplier development program (through supplier involvement) communication effort as an example of the SMMEs' commitment and cooperation attempts to build long term relationships with their suppliers. Hence, this study hypotheses the following:

H3: $\quad$ Collaborative communication of essential information between SMMEs and their suppliers has a positive influence on buyer-supplier relationship longevity.

Communication and Business Performance: An SMME's level of business performance can be dependent upon the extent of its communication effort in supplier involvement as a supplier development program (Prahinski\& Benton, 2004). Indeed, communication of essential information has been linked to improvements 
in business quality performance and ultimately to overall firm performance (Litz \& Stewart, 2000; Cater and Miller, 1989; Reid \& Adams, 2001). A study by Carter and Miller (1989) revealed that when communication of essential information occurs among other functions between the buyer and supplier firms, in addition to the buying-selling interface, the supplier's quality performance is enhanced when compared to that which is experienced when only the buying firm's purchasing department and supplier's sales department act as the inter-organizational communication channel. In addition, poor communication was reported to be the source of many supplier product problems and a fundamental weakness in the interface between buying firms and their suppliers that constrains business performance (Newman \& Rhee, 1990). This study submits that collaborative communication between SMMEs and their suppliers has a positive influence on business performance of SMMEs. This hypothesis is stated as:

H4: Collaborative communication of essential information between SMMEs and their suppliers has a positive influence on SMME business performance.

Relationship Longevity and Business Performance: The existing literature shows that firms would enjoy benefits by placing a larger volume of business with fewer suppliers using long-term contracts (Lau, 2011; Hahn, Pinto, \& Brag, 1983). The argument is that a supplier will become part of a well-managed chain through long-term relationships with its buyers and will have a long term effect on the competitiveness of the entire supply chain (Choi \& Hartley, 1996; Kotabe et al., 2003). Business performance has previously been linked to and shown as an outcome of long-term relationships and buyer-supplier coordination. A study by De Toni and Nassimbeni (1999) revealed that a long-term relationship between the buyer and the supplier stimulates the intensity of buyer-supplier coordination, which in turn, enhances firm performance. In support, a study by Carr and Pearson (1999) found that well managed long-term relationships with key suppliers have a positive influence on supplier performance of a firm. Based on the above empirical evidence, this study posits that:

H5: $\quad$ Buyer-supplier relationship longevity has a positive influence on SMME business performance

\section{Methodology}

Sample and data collection: The data for this research was collected from Gauteng Province of South Africa. The research sampling frame was the Gauteng Enterprise Propeller of South Africa. Students from the Vaal University of Technology were recruited to distribute and collect the questionnaires after appointments with target small businesses were made by telephone. Of the total of 500 questionnaires distributed, 302 usable questionnaires were retrieved for the final data analysis, representing a response rate of 60.4 percent.

Measurement Instrument and Questionnaire Design: Research scales were operationalized on the basis of previous work. Proper modifications were made in order to fit the current research context and purpose. "Supplier involvement" measure used a six-item scale adapted from Chen and Paulraj (2004). "Communication" measure used six-item scales while "business performance" used a two-item scale measure adopted from Rivard, Raymond and Verreault (2006). Finally, "relationship longevity" was measured using a six-item scale adapted from Ganesan (1994). All the measurement items were measured on a five-point Likert-type scales that was anchored by $1=$ strongly disagree to $5=$ strongly agree to express the degree of agreement.

Table 1: Sample Profile Characteristics

\begin{tabular}{|c|c|c|}
\hline Number of employees & Frequency & Percentage \\
\hline$\leqq 20$ & 152 & $50.3 \%$ \\
\hline $21-50$ & 80 & $26.5 \%$ \\
\hline$\geqq 51$ & 70 & $23.2 \%$ \\
\hline Total & 302 & $100 \%$ \\
\hline $\begin{array}{l}\text { Participants } \\
\text { experience }\end{array}$ & Frequency & Percentage \\
\hline$\leqq 5$ years & 180 & $59.6 \%$ \\
\hline $5-10$ years & 102 & $33.8 \%$ \\
\hline
\end{tabular}




\begin{tabular}{lll}
\hline$\geqq 10$ years & 20 & $6.6 \%$ \\
Total & $\mathbf{3 0 2}$ & $\mathbf{1 0 0 \%}$ \\
Industry & Frequency & Percentage \\
Manufacturing & 122 & $40.4 \%$ \\
Service & 180 & $59.6 \%$ \\
Total & $\mathbf{3 0 2}$ & $\mathbf{1 0 0 \%}$ \\
\hline
\end{tabular}

Respondent Profile: Table 1 presents the profile of the participants. The profile indicates that about three quarters of the participating small businesses employed less than 50 workers (76.8\%), while less than a quarter had a workforce above 51 employees (23.2\%). More than half of the participants had less than 5 years working experience (59.6\%), more than a quarter of the participants had 5-10 years working experience (33.8\%), and less than a quarter had above 10 years working experience (6.6\%). The study also indicated that the majority of the participants belonged to the service sector, which occupied $59.6 \%$, while the manufacturing sector occupied the remainder.

\section{Results of data Analysis}

Table 2: Accuracy Analysis Statistics

\begin{tabular}{|c|c|c|c|c|c|c|c|c|c|c|c|}
\hline \multirow{2}{*}{\multicolumn{2}{|c|}{$\begin{array}{l}\text { Research } \\
\text { Construct }\end{array}$}} & \multicolumn{4}{|c|}{ Descriptive Statistics } & \multicolumn{2}{|c|}{ Cronbach's Test } & \multirow{3}{*}{$\begin{array}{l}\text { C.R. } \\
\text { Value }\end{array}$} & \multirow[b]{2}{*}{$\begin{array}{l}\text { AVE } \\
\text { Value }\end{array}$} & \multirow[b]{2}{*}{$\begin{array}{l}\text { Highest } \\
\text { Shared } \\
\text { Variance }\end{array}$} & \multirow[b]{2}{*}{$\begin{array}{l}\text { Factor } \\
\text { Loading }\end{array}$} \\
\hline & & \multicolumn{2}{|c|}{ Mean Value } & \multicolumn{2}{|c|}{$\begin{array}{l}\text { Standard } \\
\text { Deviation }\end{array}$} & \multirow{2}{*}{\begin{tabular}{|l|}
$\begin{array}{l}\text { Item- } \\
\text { total }\end{array}$ \\
0.533
\end{tabular}} & \multirow[t]{2}{*}{ ? Yalue } & & & & \\
\hline \multirow{6}{*}{ SI } & SI1 & 3.973 & \multirow{6}{*}{4.299} & 0.643 & \multirow{6}{*}{0.610} & & & & \multirow{6}{*}{0.435} & \multirow{6}{*}{0.476} & 0.542 \\
\hline & SI2 & 4.520 & & 0.551 & & 0.681 & \multirow{5}{*}{0.866} & \multirow{5}{*}{0.867} & & & 0.867 \\
\hline & SI3 & 4.507 & & 0.575 & & 0.651 & & & & & 0.851 \\
\hline & SI4 & 4.380 & & 0.671 & & 0.794 & & & & & 0.747 \\
\hline & SI5 & 4.407 & & 0.602 & & 0.773 & & & & & 0.754 \\
\hline & SI6 & 4.007 & & 0.617 & & 0.568 & & & & & 0.526 \\
\hline \multirow{6}{*}{$\mathrm{CO}$} & $\mathrm{CO} 1$ & 4.260 & \multirow{6}{*}{4.420} & 0.560 & \multirow{6}{*}{0.576} & 0.463 & \multirow{6}{*}{0.878} & \multirow{6}{*}{0.883} & \multirow{6}{*}{0.452} & \multirow{6}{*}{0.476} & 0.767 \\
\hline & $\mathrm{CO} 2$ & 4.513 & & 0.539 & & 0.740 & & & & & 0.772 \\
\hline & $\mathrm{CO} 3$ & 4.467 & & 0.608 & & 0.781 & & & & & 0.813 \\
\hline & $\mathrm{CO} 4$ & 4.453 & & 0.596 & & 0.743 & & & & & 0.774 \\
\hline & $\mathrm{CO} 5$ & 4.353 & & 0.556 & & 0.668 & & & & & 0.735 \\
\hline & CO6 & 4.473 & & 0.598 & & 0.725 & & & & & 0.611 \\
\hline \multirow{6}{*}{ LR } & LR1 & 4.373 & \multirow{6}{*}{4.318} & 0.607 & \multirow{6}{*}{0.586} & 0.596 & \multirow{6}{*}{0.913} & \multirow{6}{*}{0.914} & \multirow{6}{*}{0.548} & \multirow{6}{*}{0.343} & 0.939 \\
\hline & LR2 & 4.360 & & 0.558 & & 0.775 & & & & & 0.958 \\
\hline & LR3 & 4.307 & & 0.600 & & 0.826 & & & & & 0.743 \\
\hline & LR4 & 4.360 & & 0.626 & & 0.660 & & & & & 0.844 \\
\hline & LR5 & 4.233 & & 0.560 & & 0.876 & & & & & 0.723 \\
\hline & LR6 & 4.273 & & 0.565 & & 0.825 & & & & & 0.546 \\
\hline & BP1 & 4.087 & 4000 & 0.633 & 0621 & 0.867 & 0070 & & & & 0.899 \\
\hline BP & BP2 & 4.073 & 4.080 & 0.635 & 0.634 & 0.867 & 0.929 & 0.927 & 0.775 & 0.257 & 0.959 \\
\hline
\end{tabular}

Measurement Instrument Validation: Analysis of Moment Structures 22 (AMOS 22) was used to test the conceptual model fit, reliability and validity of measures using confirmatory factor analysis (CFA) that combined each research construct measured by reflective indicators (Anderson and Gerbing, 1988). First, a 
confirmatory factor analysis model that included the four research constructs was assessed to check the model fit. The overall model statistics indicated that the ratio of chi-square (CMIN=504.988) to degrees of freedom $(\mathrm{DF}=142)$, i.e. $\left(\chi^{2} / \mathrm{df}\right)=3.556$, the goodness-of-fit-index (GFI), the comparative-fit-index (CFI), the incremental fit index (IFI), the relative fit index (RFI), the normed fit index (NFI) and the root mean square error of approximation (RMSEA) are 0.866, 0.923, 0.924, 0.863, 0.897and 0.092, respectively. All these measures were considered statistically significant and therefore, confirming a robust and acceptable model fit (Bentler, 1990; Bentler \& Bonett, 1980). Table 2 presents key descriptive statistics of reliability analyses for the four constructs. The composite reliabilities are above 0.85 and therefore well above the recommended minimum threshold of 0.6 (Bagozzi and Yi, 1988). The average variance extracted (AVE) ranges from 0to 0.78 (Fornell and Larcker, 1981). In addition, all of the coefficient alpha values exceeded 0.8 and according to Nunnally (1978), the threshold value is 0.7 and all the factor loadings were significantly above the recommended thresh-hold of 0.5 (Anderson and Gerbing, 1988). These results confirm measurement reliability and provide support for an acceptable degree of internal consistency between the corresponding indicators and satisfied the minimum requirements for justifying convergent validity (Bagozzi, Yi, and Phillips, 1991).

To investigate the distinctiveness of constructs, the assessment of discriminant validity wastested. Although, the inter-correlations between the research constructs were relatively high, they werestill marginally acceptable (Hulland, 1999). However, to further check discriminant validity the current study compared the average variance-extracted (AVE) estimates of the measurements with the square of the parameter estimate between the measurements. If the average variance-extracted estimates of the constructs were found to be greater than the square of the correlation between two constructs, then, evidence exist to justify discriminant validity (Fornell \& Larcker, 1981). For example, the relationship between "Business Performance" and "Longterm Relationship," yielded an AVE estimate for "Business Performance" of 0.775 while that of "Long-term Relationship" was 0.548 . These two average variance-extracted estimates weregreater than the square of the correlation between "Business Performance" and "Long-term Relationship" $\left(0.586^{\circ} 2=0.343\right)$; see Table 4. Therefore, the result provides support forthe discriminant validity of the constructs. Overall, the two approaches used to check discriminant validity suggested that discriminant validities indeed existed.

Table 3: Inter-construct correlation Matrix

\begin{tabular}{|c|c|c|c|c|}
\hline Research Constructs & SI & CO & LR & BP \\
\hline Supplier Involvement (SI) & 1 & & & \\
\hline Communication (CO) & $.690^{* *}$ & 1 & & \\
\hline Relationship & $.486^{* *}$ & $.586^{* *}$ & 1 & \\
\hline Business Performance (BP) & $.373^{* *}$ & $.337^{* *}$ & $.507^{* *}$ & 1 \\
\hline
\end{tabular}

**. Correlation is significant at the 0.01 level (2-tailed).

Table 4: Highest Shared Variance

\begin{tabular}{lllll}
\hline & SI & CO & LR & BP \\
\hline SI & 1 & & & \\
CO & $\mathbf{0 . 4 7 6}$ & 1 & & \\
LR & 0.236 & $\mathbf{0 . 3 4 3}$ & 1 & \\
BP & 0.139 & 0.114 & $\mathbf{0 . 2 5 7}$ & 1 \\
\hline
\end{tabular}

Path Modeling: Structural equation modeling (SEM) was conducted to test the validity of the proposed model and the hypotheses also usingAMOS 22 statistical software program. Table 4 presents the estimated model, illustrating the direction and magnitude of the impact of the standardized path coefficients. Recommended statistics for the overall structural equation model assessment also showed acceptable fit of 
$\chi^{2} / \mathrm{df}=2.471 ; \mathrm{GFI}=0.894 ; \mathrm{CFI}=0.952 ; \mathrm{IFI}=0.953 ; \mathrm{RFI}=0.902 ; \mathrm{NFI}=0.924$ and RMSEA=0.071.The model's fit, as indicated by these indexes, was deemed satisfactory, thereby providing a good basis for testing the hypothesized paths. The parameter estimates of the structural model exhibited the direct effects of one construct on the other. A significant coefficient at a certain level of alpha thus reveals a significant relationship among the latent constructs (see Table 5). The results in Table 4 provided support for the all the proposed five research hypotheses. The path coefficients for H1, H2, H3, H4 and H5 are 0.819, 0.225, 0.328, 0.05 and 0.474 respectively. All coefficients for the hypotheses were significant at a confidence level ( $p$ value) of 0.01 .

Table 5: Results of Structural Equation Model Analysis

\begin{tabular}{llc}
\hline Path & Hypothesis & Coefficients \\
\hline Supplier Involvement (SI) $\rightarrow$ Communication (CO) & H1 & $\mathbf{0 . 8 2}$ \\
Supplier Involvement (SI) $\rightarrow$ Long-term Relationship (LR) & H2 & $\mathbf{0 . 2 3}$ \\
Communication (CO) $\rightarrow$ Long-term Relationship (LR) & H3 & $\mathbf{0 . 3 3}$ \\
Long-term Relationship (LR) $\rightarrow$ Business Performance (BP) & H4 & $\mathbf{0 . 0 5}$ \\
Communication (CO) $\rightarrow$ Business Performance (BP) & H5 & $\mathbf{0 . 4 7}$
\end{tabular}

Structural Model Fits: $\chi^{2} / \mathrm{df}=2.471 ; \mathrm{GFI}=0.894 ; \mathrm{CFI}=0.952 ; \mathrm{IFI}=0.953 ; \mathrm{RFI}=0.902 ; \mathrm{NFI}=0.924$ and RMSEA $=0.071$.

aSignificance Level $p<0.05$; bSignificance Level $p<0.01$; cSignificance Level $p<0.001$.

\section{Discussion and Conclusion}

The study worked towards determining the influence of supplier involvement on business performance, with supplier-buyer long-term relationship and supplier-buyer communication as influential mediators. This study intended to contribute to theoretical understanding in supply chain management, from the perspective of the SMEs in South Africa. More specifically, the study examined this using the Relational view (Penrose, 1959). Five hypotheses were proposed for the study and tested. Research hypotheses were supported to some degree by empirical findings. As interred by the empirical findings, supplier involvement has a positive impact on communication (0.82), which is much stronger than its influence on long-term relationship between supplier and buyer (0.23). This highlights the significance of the supplier's active participation in product development that contributes to good exchange of information between the supplier and buyer. Although the influence is positive, the impact of communication on long-term relationship is surprisingly weak (0.33), as is the influence of a long-term relationship on business performance (0.05). Such a weak relation between long-term relationship and business performance may be explained by possible differences in expectations of the supplier and the buyer, pertaining to the shared values, information and contributions in collaborations (Andersen, Christenssen \& Tamgaard, 2009). The different types of collaborations that suppliers and buyers engage in and how long the collaborations are intended to last may also have an underlying role in the longevity of the relationship. Comparatively, the influence of communication on business performance was moderately stronger $(0.47)$ than the influence of a long-term relationship on the same (0.05).

Implications of the Study: The study contributes meaningfully towards both practical and academic insights pertaining to supply chain management and the resultant business performance. Fundamentally, there are important insights on the significance of supplier involvement and communication between suppliers and buyers. Moreover, the study speaks to alternatives of enhancing business performance for SMMEs in South Africa by enriching relations between suppliers and buyers. As increasing importance is placed on South Africa's growth of SMMEs (Department of Trade and Industry, 2005), their successful management and performance is vital to the growth of the economy. Contributions to academia point to the ability of supplier involvement to enhance business performance - through the improvement of communications between suppliers and buyers. The significance of the causal relationship between the two not only confirms their importance to SMMEs, but also identifies them as vital influencers within supply chain management. The 
performance of a business has a bearing on the degree to which sharing of information between suppliers and their buyers is effective (Turner, Varghese, \& Walker, 2008). The study infers, however, that acceptable levels of communications between SMME suppliers and buyers in South Africa do not necessarily translate to longer relationships between the two parties. This may be peculiar to SMMEs included in the study and be reflective of SMMEs in contexts outside of South Africa.

The study also questions the importance the longevity on relationships between SMME suppliers and their buyers in South Africa. This alludes to practical implications surrounding relationships between suppliers and buyers. Empirical causal relationships suggest that, practically, the longevity of the supplier-buyer relationship does little to determine business performance. This may reflect the reality that SMMEs in South Africa have particular determinants for relationship longevity or that maintenance of long-term relationships is considered separate from the supply chain management processes. Moreover, the context of relationship management may well be particular to a South African business context that differs from relationship management principles held by larger enterprises or Western economies. Structural changes that result from Black Economic Empowerment (BEE) measures that encourage growth in SMMEs, may have significant influence on relationships between business partners, and the longevity thereof. Determinants of the longevity of the relationships between suppliers and buyers may be directed by partnerships recommended by South Africa's changing BEE policies. This may directly affect certain SMMEs to continuously foster relationships that are economically more beneficial to them, based on changing BEE recommendations (Paton, 2013). As such, SMMEs may be inclined to discontinue some relationships in favor of more beneficial ones. In summary, this study revealed the importance of collaborative communication as a value adding aspect in supply chain management and business performance. This adds considerably to B2B marketing literature and supplier relationship practices that need to be explored within the South African context that pertains to SMMEs. Although it is supported in literature that communication is essential for relationship longevity between the supplier and buyer, it is important to explore the relevance of certain external market factors that influence the maintenance of relationships with business partners that are particular to SMMEs in South Africa.

Limitations and Future Research: Although the study highlighted the importance of both communication and longevity of supplier-buyer relationships, it has been limited in its scope to account for constraints in relationship management between suppliers and buyers. There are sufficient theoretical and practical justifications for communication being supported by supplier involvement. However, the link between communication and longevity of supplier-buyer relationship has not been delved into sufficiently, owing to possible context specific precursors that were not considered at the time of the study. Perhaps too, this study could have been affected externally by changes to economic incentivizing policies, such as the Black Economic Empowerment (BEE). Due to possible effects of BEE policies on B2B practices, most SMEEs may have been influenced in the interim, and this may not necessarily be the SMMEs' long-term operational preference. Future researches may also call for deeper understanding of longevity of relationships between SMME suppliers and their buyers. Kotabe et al. (2003) and Chen and Paulraj (2004) highlighted the fundamental strategic role played by relationship management of suppliers, which has the potential to be justified practically. This study noted theoretically the importance of longevity of relationships between suppliers and buyers, and this needs to be investigated further, particularly with reference to SMMEs in South Africa. The prospect of effective supply chain management being dependent on relationship management that is supported by communication between suppliers and buyers may well direct future research in this regard.

\section{References}

Andersen, P. H., Christenssen, P. R. \& Tamgaard, T. (2009). Diverging expectations in buyer-seller relationships: Institutional contexts and relationship norms. Industrial Marketing Management, 38(7), 841-824.

Anderson, J. C. \& Gerbing, D. W. (1988). Structural equation modeling in practice: A review and recommended two-step approach. Psychological Bulletin, 103, 411-423.

Athaide, G. A. \& Klink, R. R. (2009). Managing seller-buyer relationships during new product development. Journal of Product Innovation Management, 26(5), 566-77. 
Bagozzi, R. P. \& Youjae, Y. (1988). On the evaluation of Structural Equation Models. Journal of the Academy of Marketing Science, 16, 74-94.

Bentler, P. M. \& Bonett, D. G. (1980). Significance tests and goodness-of-fit in the analysis of covariance structures. Psychological Bulletin, 88, 588-600.

Bentler, P. M. (1990). Comparative fit indexes in structural models. Psychological Bulletin, 107, 238-246.

Bonaccorsi, A. \& Lipparini, A. (1994). Strategic partnerships in new product development: An Italian case study. Journal of Product Innovation Management, 11(2), 134-145.

Burt, D., Petcavage, S. \& Pinkerton, R. (2010). Supply Management. New York: McGraw Hill

Carr, A. S. \& Pearson, J. N. (1999). Strategically managed buyer-seller relationships and performance outcomes. Journal of Operations Management, 17(5), 497-519.

Carter, J. R. \& Miller, J. G. (1989). The impact of alternative vendor/buyer communication structures on the quality of purchased materials. Decision Sciences, 20, 759-776.

Chen, I. J. \& Paulraj, A. (2004). Towards a theory of supply chain management: The constructs and measurements. Journal of Operations Management, 22, 119-150.

Chen, I. J. \& Paulraj, A. (2004). Understanding supply chain management: Critical research and a theoretical framework. International Journal of Production Research, 42(1), 131-163.

Choi, T. Y. \& Hartley, J. L. (1996). An exploration of supplier selection practices across the supply chain. Journal of Operations Management, 14, 333-343.

Corsten, D. \& Felde, J. (2005). Exploring the performance effects of key-supplier collaboration: An empirical investigation into Swiss buyer-supplier relationships.International Journal of Physical Distribution \& Logistics Management, 35(6), 445-461.

De Toni, A. \& Nassimbeni, G. (1999), Buyer-supplier operational practices, sourcing policies and plant performance: Result of an empirical research. International Journal of Production Research, 37, 597619.

Department of Trade and Industry. (2005). Integrated Strategy on the Promotion of Entrepreneurship and Small Enterprises, Republic of South Africa: Department of Trade and Industry.

Dyer, J. \& Singh, H. (1998). The relational view: Cooperative strategy and sources of interorganizational competitive advantage. Academy of Management Review, 23(4), 660-679.

Eggert, A. \& Ulaga, W. (2010). Managing customer share in key supplier relationships. Industrial Marketing Management, 28, 1346-1355.

Fornell, C. \& Larcker, D. F. (1981). Evaluating structural equation models with unobservable variables and measurement error. Journal of Marketing Research, 18(1), 39-50.

Galt, J. D. A. \& Dale, B. G. (1991). Supplier development: A British case study. International Journal of Purchasing and Materials Management, 27(1), 19-24.

Hahn, C. K., Pinto, P. A. \& Brag, D. J. (1983). Just-in-time purchasing and the partnership strategy. European Journal of Purchasing and Supply Management, 1, 2-10.

Homburg, C. \& Pflesser, C. (2003). A multiple-layer model of market-orientated organizational culture: Measurement issues and performance outcomes. Journal of Marketing Research, 37, 449-462.

Hooley, G. I., Greenley, G. E., Cadogan, J. W. \& Fahy, J. (2005). The performance impact of marketing resources. Journal of Business Research, 58(1), 18-27.

Hulland, J. (1999). Use of Partial Least Squares (PLS) in strategic management research: A review of four recent studies. Strategic Management Journal, 20(2), 195-204.

Kamath, R. R. \& Liker, J. K. (1994). A second look at Japanese product development. Harvard Business Review, 72(6), 154-170.

Kotabe, M., Martin, X. \& Domoto, H. (2003). Gaining from vertical partnerships: Knowledge transfer, relationship duration, and supplier performance improvement in the U.S. andJapanese automotive industries. Strategic Management Journal, 24(4), 293-316.

Krause, D. R. (1999). The antecedents of buying firms' efforts to improve suppliers. Journal of Operations Management, 17, 205-224.

Lau, A. K. W. (2011). Supplier and customer involvement on new product performance: Contextual factors and an empirical test from manufacturer perspective. Industrial Management and Data Systems, 111(6), 910-942. 
Lau, A. K. W. (2011). Supplier and customer involvement on new product performance: Contextual factors and an empirical test from manufacturer perspective. Industrial Management \& Data Systems, 111(6), 910-942.

Leenders, M., Fearon, H. E., Flynn, A. E. \& Johnson, P. F. (2002). Purchasing and supply management. New York: McGraw Hill/Irwin.

Litz, R. A. \& Stewart, A. C. (2000). Trade-name franchise membership as a human resource management strategy: Does buying group training deliver 'true value' for small retailers? Entrepreneurship Theory and Practice, 25(1), 125-135.

Madhok, A. \& Tallman, S. B. (1998). Resources, transactions, and tents: Managing valuethrough inter-firm collaborative relationships. Journal of Organization Science, 9(3), 326-339.

Madlberger, M. (2009). A model of antecedents of RFID adoption intention in the supply chain, Proceedings of the 42nd Hawaii International Conference on System Sciences, 1-11.

Mehta, R., Larsen, T., Rosenbloom, B. \& Ganitsky, J. (2006). The impact of cultural differences in U.S. businessto-business export marketing channel strategic alliances. Industrial Marketing Management, 35(2), 156-165.

Moeller, S., Fassnacht, M. \& Klose, S. (2006). Framework for supplier relationship management (SRM). Journal of Business-to-Business Marketing, 13(4), 69-94.

Mohr, J. J., Fisher, R. J. \& Nevin, J. R. (1996). Collaborative communication in inter-firmrelationships: Moderating effects of integration and control. Journal of Marketing, 60(3), 103-116.

Muthusamy, S. K., White, M. A. \& Carr, A. (2007). An empirical examination of the role ofsocial exchanges in alliance performance. Journal of Managerial Issues, 19(1), 53-75.

Newman, R. G. \& Rhee, K. A. (1990). A case study of NUMMI and its suppliers. International Journal of Purchasing and Materials Management, 26(4), 15-20.

Nunnaly, J. C. (1978). Psychometric theory. New York: McGraw-Hill.

Ogden, J. A. (2006). Supply base reduction: An empirical study of critical success factors. Journal of Supply Chain Management, 42(4), 29.

Paton, C. (2013). BEE codes to hurt white SMEs. The Business Day, Available from: http://business. iafrica.com/businessday/883912.html

Penrose, E. T. (1959). The theory of the growth of the firm. New York: John Wiley.

Prahinski, C. \& Benton, W. C. (2004). Supplier evaluations: communication strategies to improve supplier performance. Journal of Operations Management, 22, 39-62.

Prahinski, C. \& Benton, W. C. (2004). Supplier evaluations: communication strategies to improve supplier performance. Journal of Operations Management, 22(1), 39-62.

Pressey, A. D., Winklhofer, H. M. \& Tzokas, N. X. (2009) Purchasing practices in small-tomedium-sized enterprises: An examination of strategic purchasing adoption, supplier evaluation and supplier capabilities. Journal of Purchasing and Supply Management, 15(4), 214-226.

Quesada, G., Rachamadugu, R., Gonzalez, M. \& Martinez, J. L. (2008). Linking order winning and external supply chain integration strategies: Supply Chain Management. An International Journal, 13(4), 296303.

Ragatz, G. L., Handfield, R. B. \& Scannell, T. V. (1997). Success factors for integrating suppliers into new product development. Journal of Product Innovation Management, 14(3), 190-202.

Reid, R. S. \& Harris, R. I. D. (2002). The determinants of training in SMEs in Northern Ireland. Journal of Education and Training, 44(8), 443-450.

Robson, M. J., Spyropoulou, S. \& Al-Khalifa, A. B. K. (2006). Anxiety of dependency in international joint ventures? An empirical study of drivers and consequences of relationship insecurity. Industrial Marketing Management, 35(5), 556-566.

Sahin, F. \& Robinson Jr, E. P. (2005). Information sharing and coordination in make-to-order supply chains. Journal of Operations Management, 23(6), 579-98.

Sarkar, M. B., Echambadi, R., Çavuşgil, S. T. \& Aulakh, P. S. (2001). The influence of complementarity, compatibility, and relationship capital on alliance performance. Journal of the Academy of Marketing Science, 29(4), 358-373.

Song, M. \& Benedetto, C. A. D. (2008). Supplier's involvement and success of radical new product development in new ventures. Journal of Operations Management, 26(1), 1-22. 
Turner, A. M., Varghese, R. \& Walker, P. (2008). Information Sharing and SMME Financing in South Africa: A survey of the landscape, North Caroliner. Political and Economic Research Council.

Ulaga, W. \& Eggert, A. (2006). Value-based differentiation in business relationships: gaining and sustaining key supplier status. Journal of Marketing, 70, 119-136.

Vorhies, D. W. \& Morgan, N. A. (2005). Benchmarking marketing capabilities for sustainedcompetitive advantage. Journal of Marketing, 69(1), 80-94.

Wagner, S. M. \& Johnson, J. L. (2004). Configuring and managing strategic supplierportfolios. Industrial Marketing Management, 33, 717-730.

Wisner, J. (2003). A Structural Equation Model of supply chain management strategies and firm performance. Journal of Business Logistics, 24(1), 1-26.

Wittmann, C. M., Hunt, S. D. \& Arnett, D. B. (2009). Explaining alliance success: Competences, resources, relational factors, and resource-advantage theory. Industrial Marketing Management, 38, 743-756.

Wong, H. \&Merrilees, B. (2007). Multiple roles for branding in international marketing. International Marketing Review, 24(4), 384-408. 